\title{
Problem-Based Learning Approach with Supported Interactive Multimedia in Physics Learning: Its Effects on Critical Thinking Abilty
}

\author{
Yeni Rima Liana ${ }^{1}$, Puji Iman Nursuhud ${ }^{2}$ \\ Universitas Negeri Semarang, Indonesia ${ }^{1}$, Universitas Negeri Yogyakarta, Indonesia ${ }^{2}$ \\ yrimaliana21@gmail.com ${ }^{1}$, nursuhudpujiiman @gmail.com²
}

Received: April $8^{\text {th }}, 2020$. Revised: May $18^{\text {th }}, 2020$. Accepted: May $19^{\text {th }}, 2020$

\author{
Keywords : \\ Interactive Multimedia; \\ Dynamic Electricity; Problem- \\ Based Learning; Critical \\ Thinking Ability
}

\begin{abstract}
In this research, interactive multimedia on dynamic electricity concepts was developed and tested. The purpose of this research was to analyze the feasibility and the effectiveness of interactive multimedia through a problembased learning approach to students' critical thinking ability. The research and development $(R \& D)$ had three stages: preliminary study, development, and field testing. The field testing was a quasi-experiment with a pretest and posttest control group design. The research subjects consisted of four lecturers as expert validators, two teachers and two groups of 72 students in a senior high school in Batang Regency, Central Java. Data were gathered by using questionnaires, observation, interviews, and written test. The results of the Normalized-gain test were 61.79 for the experiment group and 49.91 for the control group. This shows that there were differences in the increase of students' critical thinking ability between the control group and the experiment group.Therefore, it can be concluded that the application of interactive multimedia could improve students' critical thinking ability.
\end{abstract}

\section{INTRODUCTION}

Physics learning in $21 \mathrm{st}$ century is very closely related to technological development. Rapidly developing technology makes learning activities more dynamic. Learning activities that require critical thinking ability can be integrated with technologies such as interactive multimedia. The application of interactive multimedia has a positive impact as a support for learning to improve students' understanding of concepts [1]. Agreeing with this, interactive multimedia can also be used to improve problem-solving abilities [2]. In addition, the involvement of multimedia in learning activities can also improve learning achievement, positive attitudes and student motivation compared to conventional learning [3-4]. This indicates that the development of learning is in harmony with the development of technology so that media is needed that can be used to facilitate the delivery of material concepts. 
Indonesian Minister of Education and Culture Regulation No. 22 of 2016 concerning the standard process states that learning at primary and secondary levels must be held interactively, inspiratively, fun and can motivate students to actively participate in learning according to their interests and talents. But in reality, the teacher does not understand these aspects so physics tends to be learning that is abstract, difficult to understand and does not motivate students [5]. Learning that is abstract and difficult to understand can lead to negative perceptions related to the learning material. Students' negative perceptions of physics learning come from several factors such as teachers, peers and family, the community environment, and several other internal and external factors [6]. These factors influence the formation of character, attitudes, thought patterns and behavior of students in the development of perception and knowledge into a form of learning experience. This statement agrees with the results of the research by Yoon, et al [7], which shows a positive relationship between students' perceptions of physics learning activities. Therefore, physics learning can be carried out well if students have positive perceptions that are able to encourage interactive, inspirational and challenging learning so that it is easier to understand.

Technology development is growing very fast at this time, including progress of existence technology in Indonesia, especially development of mobile learning [8]. One of the media interactive learning that uses smartphones is android based e-module with Sigil Software. Sigil Software can convert word files into ePub files and can only be read by using the ePub Ebook Reader Skoob application [9]. An interactive android based e-module with Sigil Software is one of the introduction before learning activities and aimed to make students have an initial understanding, better preparation, and motivation to participate in learning and have a solution to overcome the problem being less efective in using text book that is when some students didn't read books carefully and take lots unnecessary information [10$11]$.

Interactive multimedia is an example of the use of smartphone in learning processes. The advantage of interactive multimedia is that students can access material from home without having to meet face to face, so students can read the material every time they have free time both online and offline. Interactive multimedia also provides supporting learning videos that can enrich student information. Interactive multimedia is the use of multimedia technology and the Internet to improve the quality of learning by facilitating access to resources and services, as well as distance exchange and collaboration. In the interactive learning section there is also a forum for communication discussions between teacher and students as well as students and other students.

According to Gunawan, et al [12], multimedia is a system that supports communication of teachers with students during the learning process through text, audio, image, animation, video, and graphic. The application of interactive multimedia combined with the problem-based learning approach could help students in developing several critical thinking abilities. According to Hosnan [13], problem-based learning helps students build critical thinking and problem-solving skills while developing students' ability to build their own knowledge actively. The result in line with Kim, et al [14], which stated that computer-based scaffolding is significantly impacted cognitive outcomes in problem-based learning in STEM education. Interactive multimedia has the ability to explain complex and dynamic concepts more clearly, facilitate to remember content easily, and improveunderstanding of topic content through student perspectives and ultimately make students more interested in learning [15-16]. The development of students' thinking skills can besupported by the use of interactive multimedia in learning. Nowadays, multimediaare widely used in learning. Applied multimedia in supporting problem-based learning and resultedon increase in students' cognitive and motivation [17]. In conclusion, theoretically, a combination of interactive multimedia with a problem-based learning approachsupports each other in developing students' thinking abilities, one of which is the ability to think critically. Based on the description above, it was necessary to conduct research that aims to analyze (1) the feasibility of interactive multimedia through a problem-based learning approach and (2) the effectiveness of interactive multimedia through a problem-based learning approach on students' critical thinking ability. 


\section{METHOD}

This was a research and development $(\mathrm{R} \& \mathrm{D})$ based on steps proposed by Borg \& Gall [18]: preliminary study, development, and field testing. The field testing was a quasi-experiment with a pretest and posttest control group design [19]. This method is used to determine the effectiveness of interactive multimedia products developed. The effectiveness is related to an increase in critical thinking ability. The experimental group was taught with the help of interactive multimedia, while the control group uses common modules used by the teacher. The problem solving approach was employed in both control and experimental groups as the instruction method.

The validator team consists of expert judgement (material and media expert) and physics teachers. The limited trial subjects and effectiveness were Mathematic and Natural Sciences student in SMA 2 Batang in Central Java, Indonesia. Limited trials were conducted on six students (respondents) class XII Mathematic and Natural Sciences in SMA 2 Batang academic years 2019/2020. Afterwards, the effectiveness test was carried out in one classes in the same school. Participants of the research were 72 students, where 36 students were assigned in the experimental group and 36 students in the control group.

Data collection in this research was carried out quantitatively and qualitatively. The assessment for effectiveness of the product required quantitative data from the critical thinking ability test. Moreover, to the purposes of perfecting and validating multimedia, the qualitative data were collected through users' responses in the questionnaires and observation, documentation, and interviews with users during and after the classroom implementation. Questionnaires are used to collect validation data from expert and physics teacher assessments and student responses to the use of interactive multimedia in dynamic dynamic electricity learning to improve critical thinking skills. The critical thinkingn abiliity test consists of ten descriptive questions on the dynamic electricity topic. The test included indicators of critical thinking according to Isnaneny, et al [20], which are truth-seeking, open-mindedness, analyticity, systematicity, and inquisitiveness.

Analysis of the results of the assessment of the feasibility of interactive multimedia practicality were based on student responses in the form of an assessment in the range of scores from 1 to 4 . The average score of each item for all aspects of product assessment is calculated based on the total score of all aspects of the assessment divided by the number of evaluator [21].

$$
\bar{X}=\frac{\sum X}{n}
$$

Table 1. Validation Categories

\begin{tabular}{ccc}
\hline Score Range & Categories & Indeks \\
\hline $\bar{X} \geq X_{i}+1,8$ Sbi & Excellent & 5 \\
$X_{i}+0,6 S b i<\bar{X} \leq X_{i}+1,8 S b i$ & Good & 4 \\
$X_{i}-0,6 S b i<\bar{X} \leq X_{i}+0,6 S b i$ & Fair good & 3 \\
$X_{i}-1,8 S b i<\bar{X} \leq X_{i}-0,6 S b i$ & Less & 2 \\
$\bar{X} \leq X_{i}-1,8 S b i$ & Very Less & 1 \\
\hline
\end{tabular}

Information:

$\bar{X} \quad:$ Mean Skor

$X_{i} \quad:$ Mean Ideal Score

$$
X_{i}=1 / 2(\text { maximum score }+ \text { minimum score })
$$

Sbi : Ideal Standard Deviation of Scores

$$
S b i=1 / 6(\text { maximum score }- \text { minimum score })
$$

The mean score of each item for all aspects of product appraisal is calculated based on the total score of 
the whole aspect of valuation divided by the number of appraisers. After that the mean score was converted using a standard scale rating category of five and categorized according to Table 2.

Table 2. Feasibility Criteria for Assessment Standard Five- Scale

\begin{tabular}{cc}
\hline Range of Scores & Category \\
$\bar{X}>3.4$ & Very good \\
$2.8<\bar{X} \leq 3.4$ & Good \\
$2.2<\bar{X} \leq 2.8$ & Fair \\
$1.6<\bar{X} \leq 2.2$ & Less good \\
$\bar{X} \leq 1.6$ & Not good \\
\hline
\end{tabular}

The effectiveness of interactive multimedia through a problem-based learning approach on students' critical thinking dispositions was determined based on normalized average gain scores [22].

$$
N_{\text {gain }}=\frac{S_{\text {Post-test }}-S_{\text {Pretest }}}{S_{\text {max }}-S_{\text {Pretest }}} \times 100 \%
$$

Where $\mathrm{N}$-gain is a normalized gain, $S_{\max }$ is the maximum score from the initial test and the final test, $S_{\text {post }}$ is the final test score, while $S_{\text {pre }}$ is the initial test score. The $N$-Gain scores can be classified as follows: (1) if $\mathrm{g}>70$, then the $N$-Gain is in the high category, (2) if $30 \leq \mathrm{g} \leq 70$, then the $N$-Gain is in the medium category, and (3) if $\mathrm{g}<30$, then the $N$-Gain is in the low category. The independent sample test calculation was calculated using the SPSS 23 program for Windows, aimed to differentiate two groups of samples that do not influence each other. The independent sample test calculation was calculated using the SPSS 23 program for Windows, aimed to differentiate two groups of samples that do not influence each other.

\section{RESULTS AND DISCUSSIONS}

The interactive learning media based on android was constructed by using the Sigil software for dynamic electricity materials. This media interactive learning media based on android can be used offline. The interactive learning media was divided into several sections: the opening section, main section, material section, evaluation section, and other information. The main sections of interactive learning media are shown in the following Figure 1 and Figure 2.
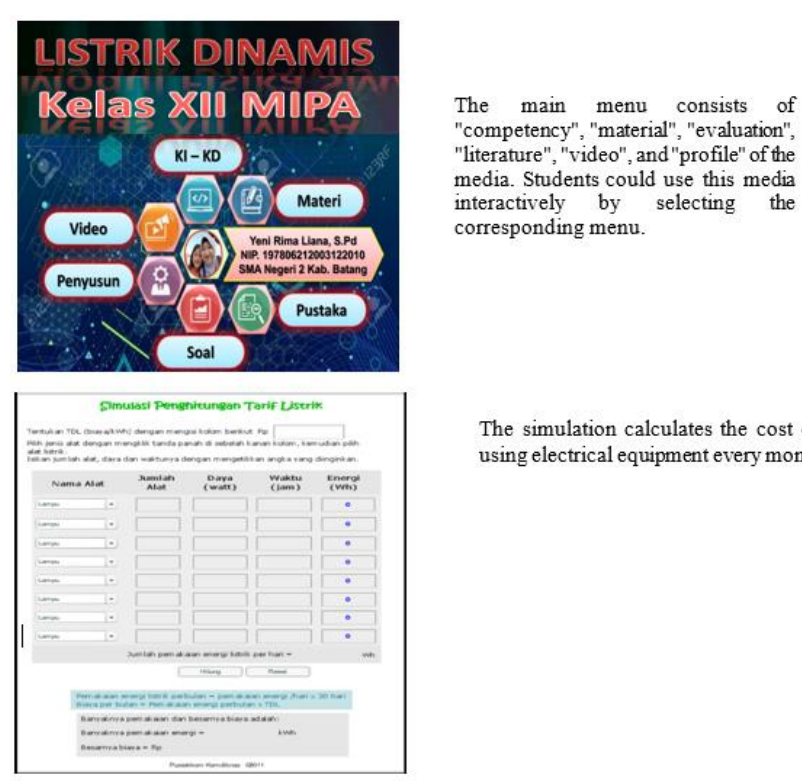

Fig 1. Example of Interactive Multimedia Displays 


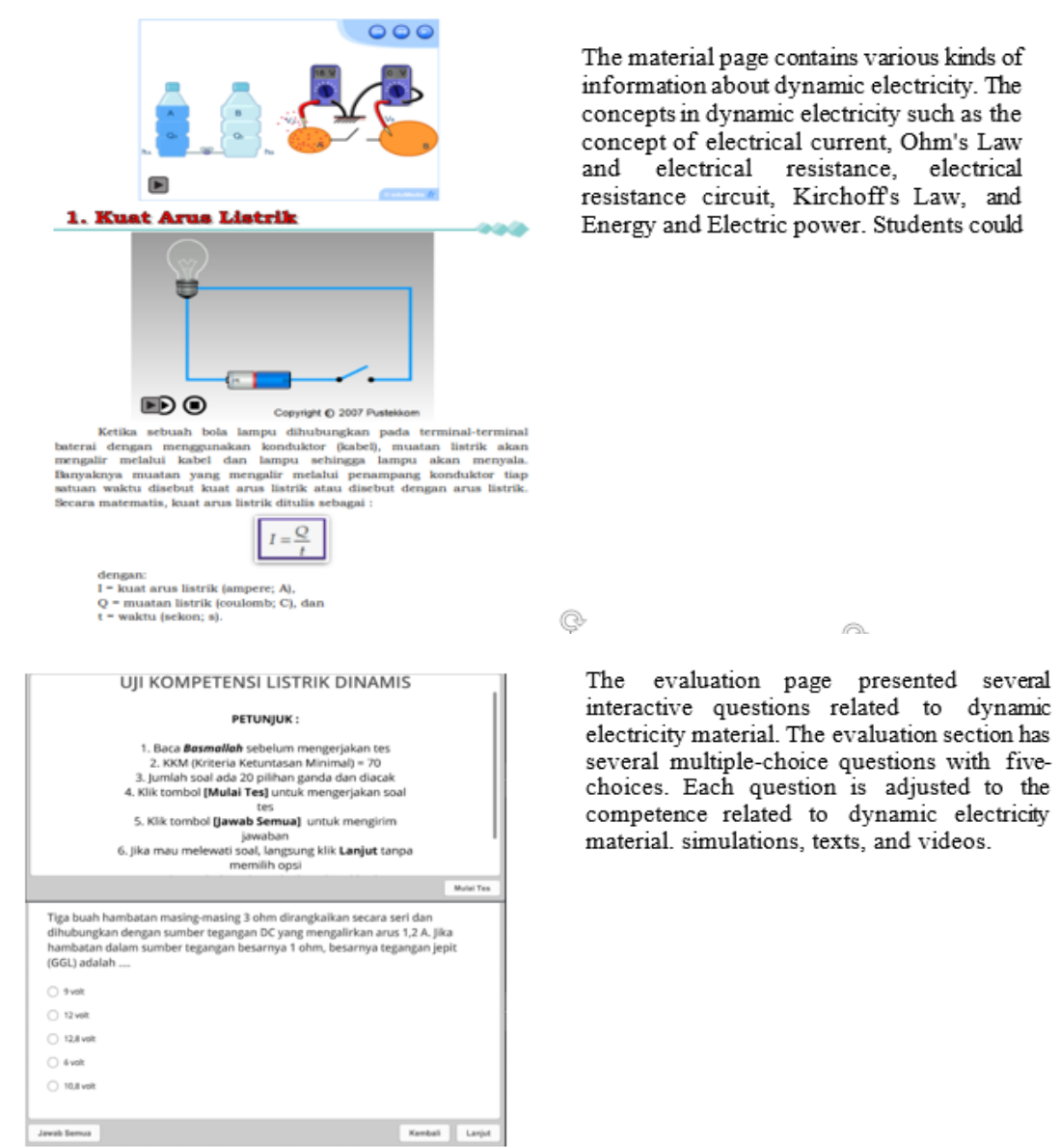

Fig 2. Virtual display of laboratories and competency tests

\section{Media Validation Result}

Revised interactive multimedia, then validated by 4 expert validators ( 2 material experts and 2 media experts) and 2 professional physics teachers. Data obtained in the form of assessments in the range of scores from 1 to 4 . Problem-based learning on dynamic electricity concepts with interactive multimedia that developed to improve students' critical thinking ability was adapted from Facione [23]. The prototype of interactive multimedia was developed and then tested to assess its feasibility as a learning media by experts' assessment questionnaire. The responses were analyzed and the result can be seen in Table 3.

Table 3. Expert Validation Results

\begin{tabular}{|c|c|c|c|c|c|c|c|c|}
\hline \multirow[t]{2}{*}{ Aspect } & \multicolumn{6}{|c|}{ Validator Scores } & \multirow[t]{2}{*}{ Average } & \multirow[t]{2}{*}{ Categorie } \\
\hline & $V_{1}$ & $\mathbf{V}_{2}$ & $\mathbf{V}_{3}$ & $\mathbf{V}_{4}$ & $V_{5}$ & $V_{6}$ & & \\
\hline Contents & 4 & 3 & 4 & 4 & 4 & 4 & 3.83 & Very good \\
\hline Language & 4 & 4 & 3 & 3 & 3 & 3 & 3.33 & Good \\
\hline Display & 4 & 4 & 3 & 4 & 3 & 4 & 3.67 & Very good \\
\hline Illustrations & 4 & 4 & 4 & 3 & 3 & 4 & 3.67 & Very good \\
\hline Tools & 3 & 3 & 4 & 4 & 4 & 3 & 3.50 & Very good \\
\hline Interactivity & 4 & 4 & 4 & 3 & 4 & 4 & 3.83 & Very good \\
\hline Audio & 3 & 4 & 3 & 3 & 4 & 3 & 3.33 & Good \\
\hline \multicolumn{7}{|c|}{ Average of all aspects } & 3.60 & Very good \\
\hline
\end{tabular}

The result showed that the content and interactivity aspect has the highest average score from experts. The total average score from experts was 3.83 (very good). Based on the result, it can be inferred that the developed interactive multimedia is suitable to use. 


\section{Students' Responses}

The limited trial aims to determine students' responses to interactive multimedia that have previously been through revisions based on the results of expert validation. During the learning process, students were given interactive multimedia for learning dynamic electricity. Researchers observed the students' attitude towards the developed product and notified the problems that arise in the use of interactive multimedia. In the end of the learning session, the students filled out questionnaires about the use of interactive multimedia. The results of the researchers' observations and the results of student responses during limited trial activities are presented in Table 4.

Table 4. Responses of Students to Interactive Multimedia

\begin{tabular}{cccc}
\hline Aspect & $\begin{array}{c}\text { Number of } \\
\text { participants }\end{array}$ & Average per aspect & Categories \\
\hline Learning & \multirow{2}{*}{6} & 3.76 & Very Good \\
Display & & 3.50 & \\
Language & & 3.24 & \\
\hline
\end{tabular}

Table 4 shows the average value of the learning aspect of 3.76 which is included in very good category, display aspect obtained an average per aspect of 3.50 with a very good category, and the language aspect of 3.24 with a good category. Suggestions from students regarding interactive multimedia are to improve the menu button and give a score in the practice questions in each sub material. Overall student assessment of Android-based interactive multimedia is included very good category and states that the product is suitable for use in physics learning.

\section{Media Effectiveness}

Test for increasing critical thinking ability using interactive multimedia was done by giving essay questions for the experimental and the control groups. The results are presented in Table 5.

Table 5. Results for Each Indicator Critical Thinking Ability

\begin{tabular}{cccc}
\hline No. & Indicators & $\begin{array}{c}\text { Experimental Group } \\
\mathbf{N = 3 6}\end{array}$ & $\begin{array}{c}\text { Control Group } \\
\mathbf{N}=\mathbf{3 6}\end{array}$ \\
\cline { 3 - 4 } & & $\mathbf{N}$-Gain & $\mathbf{N}$-Gain \\
\hline 1. & Truthseeking & 49.52 & 47.69 \\
2. & Open-mindedness & 61.79 & 49.91 \\
3. & Analyticity & 30.56 & 25.77 \\
4. & Systematicity & 46.11 & 33.21 \\
5. & Inquistiveness & 57.30 & 68.91 \\
\hline
\end{tabular}

The results show an increase in critical thinking dispositions on the Open-mindedness indicator of the experimental group with an average $\mathrm{N}$-Gain value of 61.79 included in the medium category while the mean control group $\mathrm{N}-\mathrm{Gain}$ value is 49.91 which is in the medium category.

Table 6. Independent Samples Test

\begin{tabular}{cccc}
\hline & Levene's Test for Equality of Variances & F & Sig. \\
\hline N-Gain & Equal variances assumed & 3.176 & 0.021 \\
\hline
\end{tabular}

The hypothesis was tested using independent sample t-test. Based on the results of the independent Sample t-test for the experimental and control group, the sig value is 0.021 . For the decision-making criteria for two-sided decision if the value of sig $<0.05$, this indicates a difference in the increase in learning before and after using interactive physics multimedia between the control and experiment groups.

The development of interactive multimedia aimed to simplify the learning process and students became easier to understand physics concepts. Interactive multimedia could be used as the tool to support interactive learning. The developed interactive multimedia consists of texts, images, graphics, sounds, 
videos, animations, virlabs and simulations that were put together into one unit to make it easier for students to understand dynamic electricity concepts. It consists of several parts that are integrated into a single computer software. The initial part is the opening section that contains the media title. The main part has a list of menus to access the features within the interactive multimedia. The material section consists of a combination of information in the form of text, images, videos, animations and simulations related to dynamic electricity. Based on the validation results from the experts, it was found that the developed interactive multimedia can be categorized as "Very Good". The average expert score is 3.60. There are seven indicators that determine expert validity, content, language, illustrations, equipment, interactivity, and audio.

Abstract concepts can be visualized with the help of this multimedia. According to Adawiyah, et al [24], stated that the addition of multimedia has been able to improve creative thinking skills. If the creativity of students increases, it will be easier for students to find their learning patterns that are suitable for maximum learning outcomes. The application of computer-based media that is integrated with the system is also proven to be able to increase student motivation [25]. Right motivation and creativity will highly support students' development, especially the development of special abilities, such as problem-solving skills. Interactive multimedia through a problem-based learning approach is a learning activity that involves students to try solving their problems with interactive multimedia. Problem-based learning is a good learning approach to improve learning achievement through group discussion and independent learning [26].

The multimedia was applied in these stages to support the problem-solving process. For example, to solve problems with dynamic electricity material correctly, the information presented in the interactive multimedia provides a contextual example. Interactive media displays simple animations with appropriate usage instructions. In addition, the language presented is simple and does not give rise to double meanings so that students easily understand the material contained in interactive multimedia.

In interactive multimedia, there is a simulation content in the form of a virtual lab that explains the thermal balance process. According Hermansyah, et al [27], the application of virtual labs can improve students' understanding of the concept of heat. Added that the use of virtual labs could improve students' creativity because students' creativity is very influential in students' conceptual understanding [28]. The difference in improvement in these two indicators is easy to understand because there is an initial frame of mind that already exists for each student. The learning process shows a tendency of students to maintain their frame of mind until they get a rational explanation or picture that causes a strengthening of the validity of the mindset. The shift in paradigm is in appropriate direction if the existing framework is not right.

Hypothesis testing was carried out to test the difference in improvement in the two groups. The test uses analysis of variance from independent sample t-tests using SPSS 23 software for windows. The significance value obtained was $0.021<0.05$. This shows that there are differences in the increase in students' critical thinking ability in both groups, which is the implication of the use of interactive multimedia in the learning process. Stated that animation media has a positive impact on students' critical thinking abilities, both in male and female students [29].

In the classroom implementation, interactive learning multimedia makes it easy for teachers to help students to observe problems through a video display. Stated, giving problems at the beginning of learning helps students develop thinking abilities, problem-solving, intellectual skills, and become independent learners [30]. This problem-based learning is focused on the development of student learning, not to help teachers collect information that will be given to students during the learning process.

Computer-based media is also able to prevent students from misunderstanding the concept [31]. In the process of developing high-level abilities, there is the possibility of miss thinking disposition, and the application of interactive multimedia can prevent that from happening. This shows that learning with 
interactive multimedia was effective in improving students' disposition of thinking and maintain its development in the right direction.

\section{CONCLUSION AND SUGGESTION}

Based on the result of the research, it can be concluded that (1) thedynamic electricity interactive multimedia that develop based on problem-based learning can be used as a supplementary tool in learning process; (2) The highest improvement from critical thinking disposition was on the openmindedness indicator and the lowest on analyticity indicator; (3) the developed dynamic electricity interactive multimedia can improve the ability of critical thinking of the students.

The authors provide suggestions for further research that can apply interactive learning media to examine other thinking skills. Interactive multimedia must be adapted to the skills that will be developed. For physics teachers, this development research can be used to improve students' understanding of concepts in dynamic electric material. As a follow up, the teacher can develop similar android based e-modules with different Basic Competencies. Utilization of products in learning can be synergized with learning approaches based on student centered learning, HOTS oriented learning models, and enjoyable learning methods.

\section{ACKNOWLEDGMENTS}

Thank you to the head master and student of class XII Mathematic and Natural Sciences in SMAN 2 Batang, Centra Java, Indonesia.

\section{REFERENCES}

[1] Andarini, H. D., Swasty, W., \& Hidayat, D. (2016, May). Designing the interactive multimedia learning for elementary students grade $1 \mathrm{st}-3 \mathrm{rd}$ : A case of plants (Natural Science subject). In 2016 4th International Conference on Information and Communication Technology (ICoICT) (pp. 1-5). IEEE.

[2] Ramganesh, E. (2012). Effect of self-regulatory strategies with interactive multimedia on problem solving ability of higher secondary students in Physics. Shodh Sanchayan, 3 (2): 1-5.

[3] Lee, T. T., \& Osman, K. (2012). Interactive multimedia module in the learning of electrochemistry: effects on students' understanding and motivation. Procedia-Social and Behavioral Sciences, 46: 1323-1327.

[4] Leow, F. T., \& Neo, M. (2014). Interactive multimedia learning: Innovating classroom education in a Malaysian university. Turkish Online Journal of Educational Technology-TOJET, 13(2): 99110.

[5] Arief, M. K., Handayani, L., \& Dwijananti, P. (2012). Identifikasi Kesulitan Belajar Fisika Pada Siswa RSBI: Studi Kasus Di RSMABI Se Kota Semarang. UPEJ Unnes Physics Education Journal, 1(2).

[6] Checkley, D. (2010). High School Students' Preception of Physics.

[7] Yoon, S. Y., Suh, J. K., \& Park, S. (2014). Korean students' perceptions of scientific practices and understanding of nature of science. International Journal of Science Education, 36(16): 2666-2693.

[8] Januszewski, A., \& Molenda, M. (Eds.). (2013). Educational technology: A definition with commentary. Routledge.

[9] Hill, M., Sharma, M. D., \& Johnston, H. (2015). How online learning modules can improve the representational fluency and conceptual understanding of university physics students. European 
Problem-Based Learning Approach with Supported Interactive Multimedia in Physics Learning: Its Effects on Critical Thinking Abilty Yeni Rima Liana, Puji Iman Nursuhud

Journal of Physics, 36(4): 045019.

[10] Chen, Z., Stelzer, T., \& Gladding, G. (2010). Using multimedia modules to better prepare students for introductory physics lecture. Physical Review Special Topics-Physics Education Research, 6(1): 010108.

[11] Sadaghiani, H. R. (2011). Using multimedia learning modules in a hybrid-online course in electricity and magnetism. Physical Review Special Topics-Physics Education Research, 7(1): 010102.

[12] Gunawan, G., Harjono, A., Herayanti, L., \& Husein, S. Problem-Based Learning Approach with Supported Interactive Multimedia in Physics Course: Its Effects on Critical Thinking Disposition. Journal for the Education of Gifted Young Scientists, 7(4): 1075-1089.

[13] Hosnan, M. (2014). Pendekatan saintifik dan kontekstual dalam pembelajaran abad 21: Kunci sukses implementasi kurikulum 2013. Bogor: Ghalia Indonesia.

[14] Kim, N. J., Belland, B. R., \& Walker, A. E. (2018). Effectiveness of Computer-Based Scaffolding in the Context of Problem-Based Learning for Stem Education: Bayesian Meta-analysis. Educational Psychology Review, 30(2): 397-429.

[15] Hwang, I., Tam, M., Lam, S. L., \& Lam, P. (2012). Review of Use of Animation as a Supplementary Learning Material of Physiology Content in Four Academic Years. Electronic Journal of eLearning, 10(4): 368-377.

[16] Chachil, K., Engkamat, A., Sarkawi, A., \& Shuib, A. R. A. (2015). Interactive multimedia-based mobile application for learning Iban language (I-MMAPS for learning Iban language). ProcediaSocial and Behavioral Sciences, 167: 267-273.

[17] Chu, J., Rittle-Johnson, B., \& Fyfe, E. R. (2017). Diagrams benefit symbolic problem-solving. British Journal of Educational Psychology, 87(2): 273-287.

[18] Borg, W. R., \& Gall, M. D. (2003). Educational Research: An Introduction Seventh Edition. Boston: Pearson Education.

[19] Campbell, D. T., \& Stanley, J. C. (2015). Experimental and quasi-experimental designs for research. Ravenio Books.

[20] Isnaneny, F. Y., Sajidan, S., \& Masykuri, M. (2018). Pengembangan Multimedia Interaktif Berbasis Problem Based Learning (PBL) Untuk Meningkatkan Kemampuan Berpikir Kritis Mahasiswa Program Studi Pendidikan Biologi UMS Pada Materi Sistem Gerak Manusia. INKUIRI: Jurnal Pendidikan IPA, 7(1): 111-120.

[21] Widoyoko, E. P. (2020). Teknik Penyusunan Instrumen Penelitian. Yogyakarta: Pustaka Pelajar.

[22] Meltzer, D. E. (2005). Relation between students' problem-solving performance and representational format. American journal of physics, 73(5): 463-478.

[23] Facione, P. A. (2011). Critical thinking: What it is and why it counts. Insight assessment, 2007(1): $1-23$.

[24] Adawiyah, R., Harjono, A., Gunawan, G., \& Hermansyah, H. (2019, February). Interactive e-book of physics to increase students' creative thinking skills on rotational dynamics concept. In Journal of Physics: Conference Series (Vol. 1153, No. 1, p. 012117). IOP Publishing.

[25] Ramadhani, R., Umam, R., Abdurrahman, A., \& Syazali, M. (2019). The effect of flipped-problem based learning model integrated with LMS-google classroom for senior high school students. Journal for the Education of Gifted Young Scientists, 7(2): 137-158.

[26] Argaw, A. S., Haile, B. B., Ayalew, B. T., \& Kuma, S. G. (2016). The effect of problem based learning (PBL) instruction on students' motivation and problem solving skills of physics. Eurasia Journal of Mathematics, Science and Technology Education, 13(3): 857-871.

[27] Hermansyah, H., Gunawan, G., Harjono, A., \& Adawiyah, R. (2019, February). Guided inquiry model with virtual labs to improve students' understanding on heat concept. In Journal of Physics: Conference Series (Vol. 1153, No. 1, p. 012116). IOP Publishing. 
JIPF, Vol. 5 No. 2, May 2020

[28] Yahya, F., Hermansyah, H., \& Fitriyanto, S. (2019). Virtual Experiment Untuk Meningkatkan Pemahaman Siswa Pada Konsep Getaran Dan Gelombang. Jurnal Pendidikan Fisika dan Teknologi, 5(1): 144-149.

[29] Mashami, R. A., \& Gunawan, G. (2018, November). The influence of sub-microscopic media animation on students' critical thinking skills based on gender. In Journal of Physics: Conference Series (Vol. 1108, No. 1, p. 012106). IOP Publishing.

[30] Ibrahim, M. (2000). Pembelajaran Kooperatif. Surabaya: University Press.

[31] Yumuşak, A., Maraş, İ., \& Şahin, M. (2015). Effects of computer-assisted instruction with conceptual change texts on removing the misconceptions of radioactivity. Journal for the Education of Gifted Young Scientists, 3(2): 23-50. 